\title{
Most cited articles: metal toxicity, oxidative stress control and induction as well as inhibition of cytochrome P450 enzymes
}

\author{
H. M. Bolt · J. G. Hengstler
}

Published online: 20 November 2010

(C) Springer-Verlag 2010

Every year, the editors of the Archives of Toxicology review their most cited publications from the previous 2 years (Table 1). Currently, our most cited paper is a review article by Beyersmann and Hartwig (2008) on carcinogenic metal compounds. The authors, in this article, comprehensively describe the key mechanisms responsible for metal carcinogenicity, namely inhibition of DNA repair, deregulation of signal transduction and oxidative stress induction. Incidentally, oxidative stress control is one of the cutting-edge topics frequently published in our journal. Therefore, the editors invited Jose M. Matés and colleagues to present a review article (2008) on how reactive oxygen species can modify intracellular signalling pathways. Their contribution is the second most cited paper in our journal. Number three on our citation ranking list is the article by Olavi Pelkonen and colleagues (2008) focusing on the induction and inhibition of cytochrome P450 enzymes, including a comprehensive overview of the most relevant compounds. The most cited original article is a systematic study on tissue distribution and toxicity of titanium dioxide nanoparticles (Fabian et al. 2008). The take home messages of our most cited articles have been summarized in Table 1 .
Table 1 Most cited articles in the Archives of Toxicology in 2008 and 2009

\begin{tabular}{|c|c|c|}
\hline No. & Author & Take home message \\
\hline 1 & $\begin{array}{c}\text { Beyersmann and } \\
\text { Hartwig } 2008\end{array}$ & $\begin{array}{l}\text { This review highlights the } \\
\text { three predominant } \\
\text { mechanisms of carcinogenic } \\
\text { metal compounds: induction } \\
\text { of oxidative stressinhibition } \\
\text { of DNA repair, } \\
\text { deregulation } \\
\text { of proliferation by induction } \\
\text { of signalling pathways }\end{array}$ \\
\hline 2 & Matés et al. 2008 & $\begin{array}{l}\text { This review summarizes } \\
\text { the mechanisms underlying } \\
\text { the modification of } \\
\text { intracellular signalling } \\
\text { pathways by reactive } \\
\text { oxygen species }\end{array}$ \\
\hline 3 & $\begin{array}{l}\text { Pelkonen } \\
\text { et al. } 2008\end{array}$ & $\begin{array}{l}\text { This comprehensive article } \\
\text { reviews inhibition and } \\
\text { induction of CYP enzymes, } \\
\text { provides lists of the most } \\
\text { relevant compounds and } \\
\text { discusses their importance } \\
\text { in drug therapy }\end{array}$ \\
\hline 4 & $\begin{array}{l}\text { Lilienblum } \\
\text { et al. } 2008\end{array}$ & $\begin{array}{l}\text { The authors summarize } \\
\text { the available in vitro } \\
\text { test systems that have } \\
\text { been established as } \\
\text { alternatives for animal } \\
\text { studies and discuss the } \\
\text { possibilities and limitations } \\
\text { of each test system. } \\
\text { Despite some progress } \\
\text { in the field of alternative } \\
\text { methods, in vivo studies } \\
\text { are still indispensable } \\
\text { tools, especially with } \\
\text { respect to health-related } \\
\text { limit values }\end{array}$ \\
\hline
\end{tabular}

H. M. Bolt $(\bowtie) \cdot$ J. G. Hengstler

Leibniz Institut für Arbeitsforschung an der TU Dortmund, Leibniz Research Centre for Working Environment and Human Factors (IfADo), Ardeystrasse 67, 44139 Dortmund, Germany e-mail: bolt@ifado.de 
Table 1 continued

\begin{tabular}{|c|c|c|}
\hline No. & Author & Take home message \\
\hline 5 & Fabian et al. 2008 & $\begin{array}{l}\text { Titanium dioxide } \\
\text { nanoparticles were intravenously } \\
\text { injected into rats. } \mathrm{TiO}_{2} \text { levels } \\
\text { were highest in the liver, followed } \\
\text { by spleen, lung and kidney. } \\
5 \mathrm{mg} / \mathrm{kg} \mathrm{TiO}_{2} \text { did not cause } \\
\text { any toxic effects over } 28 \text { days }\end{array}$ \\
\hline 6 & $\begin{array}{l}\text { Verstraeten } \\
\quad \text { et al. } 2008\end{array}$ & $\begin{array}{l}\text { Membrane biophysics } \\
\text { alterations, deregulation } \\
\text { of cell signalling, impairment of } \\
\text { neurotransmission and oxidative } \\
\text { stress are key mechanisms } \\
\text { involved in aluminium } \\
\text { and lead neurotoxicity }\end{array}$ \\
\hline 7 & Glahn et al. 2008 & $\begin{array}{l}\text { Cadmium and cobalt cause cell cycle } \\
\text { deregulation and increased steroid } \\
\text { as well as xenobiotic metabolism } \\
\text { in primary human bronchial } \\
\text { epithelial cells in an in vivo } \\
\text { relevant concentration range }\end{array}$ \\
\hline 8 & Liebers et al. 2008 & $\begin{array}{l}\text { This review summarizes } \\
\text { the mechanisms of endotoxin } \\
\text { recognition and its effects on } \\
\text { human health }\end{array}$ \\
\hline 9 & Calabrese 2009 & $\begin{array}{l}\text { The author criticizes the widely } \\
\text { applied toxic threshold model, } \\
\text { suggesting it poorly predicts } \\
\text { responses in the low dose zone }\end{array}$ \\
\hline 10 & Schug et al. 2008 & $\begin{array}{l}\text { Sandwich cultures with rat } \\
\text { hepatocytes can be applied } \\
\text { to study methapyrilene-induced } \\
\text { alterations in gene expression } \\
\text { at in vivo relevant concentrations }\end{array}$ \\
\hline 11 & $\begin{array}{l}\text { Nishimura } \\
\text { et al. } 2008\end{array}$ & $\begin{array}{l}\text { Oxidative stress is critical in the } \\
\text { development of fenofibrate- } \\
\text { induced hepatocellular } \\
\text { preneoplastic foci in rats }\end{array}$ \\
\hline 12 & $\begin{array}{l}\text { Manna } \\
\text { et al. } 2008\end{array}$ & $\begin{array}{l}\text { The triterpenoid saponin arjunolic } \\
\text { acid protects against arsenic- } \\
\text { induced cardiotoxicity in mice }\end{array}$ \\
\hline 13 & $\begin{array}{l}\text { Mahmud } \\
\text { et al. } 2009\end{array}$ & $\begin{array}{l}\text { Arsenic-induced eryptosis } \\
\text { (apoptosis-like cell death of } \\
\text { erythrocytes) by a } \mathrm{Ca}^{2+} \text { and } \\
\text { ceramide dependent mechanism }\end{array}$ \\
\hline 14 & $\begin{array}{l}\text { Tum and } \\
\text { Borlak } 2008\end{array}$ & $\begin{array}{l}\text { Gene expression profiling in human } \\
\text { hepatocytes identifies early } \\
\text { signals of hepatotoxicity }\end{array}$ \\
\hline 15 & Yang et al. 2009 & $\begin{array}{l}\text { This review article addresses the } \\
\text { controversial question whether } \\
\text { tea polyphenols are anti- } \\
\text { carcinogenic in humans }\end{array}$ \\
\hline 16 & $\begin{array}{l}\text { Westerink } \\
\quad \text { et al. } 2008\end{array}$ & $\begin{array}{l}\text { The authors present in vitro systems } \\
\text { for the identification of human } \\
\text { and rat Ah receptor activators } \\
\text { based on data from } 119 \\
\text { compounds }\end{array}$ \\
\hline
\end{tabular}

Table 1 continued

\begin{tabular}{|c|c|c|}
\hline No. & Author & Take home message \\
\hline 17 & $\begin{array}{l}\text { Cederbaum } \\
\text { et al. } 2009\end{array}$ & $\begin{array}{l}\text { CYP2E1 plays a crucial role in } \\
\text { alcohol-induced liver toxicity }\end{array}$ \\
\hline 18 & $\begin{array}{l}\text { Adam and } \\
\text { Laufs } 2008\end{array}$ & $\begin{array}{l}\text { Many of the effects of statins are caused } \\
\text { by inhibition of isoprenoids, which } \\
\text { serve as attachments for small Rho } \\
\text { GTPases to the cell membrane }\end{array}$ \\
\hline 19 & Settels et al. 2008 & $\begin{array}{l}\text { Human CYP2E1 mediates formation } \\
\text { of the carcinogenic metabolite } \\
\text { glycidamide from acrylamide }\end{array}$ \\
\hline 20 & $\begin{array}{l}\text { Strassburg } \\
\quad \text { et al. } 2008\end{array}$ & $\begin{array}{l}\text { This is a comprehensive review about } \\
\text { the human UDP } \\
\text { glucuronosyltransferase } \\
\text { 1A gene family: nomenclature, } \\
\text { genetic variants and } \\
\text { disease relevance }\end{array}$ \\
\hline 21 & $\begin{array}{l}\text { Rezende } \\
\text { et al. } 2008\end{array}$ & $\begin{array}{l}\text { Polymorphisms of the human vitamin D } \\
\text { receptor gene modulate circulating } \\
\text { levels of lead in exposed subjects }\end{array}$ \\
\hline 22 & Kehe et al. 2008 & $\begin{array}{l}\text { Poly(ADP-ribose) polymerase (PARP) } \\
\text { contributes to cell fate decision } \\
\text { between apoptosis and necrosis }\end{array}$ \\
\hline 23 & $\begin{array}{l}\text { Sugawara } \\
\quad \text { et al. } 2008\end{array}$ & $\begin{array}{l}\text { Perinatal co-exposure to } \\
\text { methylmercury and } \\
\text { polychlorinated biphenyls } \\
\text { produced no synergistic } \\
\text { effects on neurobehavioral } \\
\text { development in mice }\end{array}$ \\
\hline 24 & Grotto et al. 2009 & $\begin{array}{l}\text { Low level sub-chronic administration } \\
\text { of methylmercury causes } \\
\text { hypertension in rats }\end{array}$ \\
\hline 25 & $\begin{array}{r}\text { Naraharisetti } \\
\text { et al. } 2008\end{array}$ & $\begin{array}{l}\text { No toxicological interaction } \\
\text { between arsenic and malathion } \\
\text { could be identified }\end{array}$ \\
\hline 26 & $\begin{array}{l}\text { Lankisch } \\
\text { et al. } 2008\end{array}$ & $\begin{array}{l}\text { The UDP-glucuronosyltransferase } \\
1 \mathrm{~A} 3 \text { gene is regulated } \\
\text { by the Ah receptor }\end{array}$ \\
\hline 27 & Son et al. 2008 & $\begin{array}{l}\text { Perfluorooctanoic acid, } \\
\text { a widespread environmental } \\
\text { pollutant, causes hepatotoxicity } \\
\text { in mice }\end{array}$ \\
\hline 28 & Dorn et al. 2008 & $\begin{array}{l}\text { The synthetic steroid } \\
\text { tetrahydrogestrinone illegally } \\
\text { used for doping in sports, } \\
\text { induces micronuclei in V79 cells. } \\
\text { Therefore, a genotoxic hazard } \\
\text { for misusing the compounds } \\
\text { by athletes cannot } \\
\text { be ruled out }\end{array}$ \\
\hline 29 & $\begin{array}{l}\text { Florl and } \\
\quad \text { Schulz } 2008\end{array}$ & $\begin{array}{l}\text { This review describes the role of } \\
\text { chromosomal instability for } \\
\text { progression of urothelial } \\
\text { carcinomas }\end{array}$ \\
\hline 30 & Khalil et al. 2008 & $\begin{array}{l}\text { Panax ginseng extract protects } \\
\text { against EDTA-induced } \\
\text { toxicity }\end{array}$ \\
\hline
\end{tabular}




\section{References}

Adam O, Laufs U (2008) Antioxidative effects of statins. Arch Toxicol 82(12):885-892

Beyersmann D, Hartwig A (2008) Carcinogenic metal compounds: recent insight into molecular and cellular mechanisms. Arch Toxicol 82(8):493-512

Calabrese EJ (2009) The road to linearity: why linearity at low doses became the basis for carcinogen risk assessment. Arch Toxicol 83(3):203-225

Cederbaum AI, Lu Y, Wu D (2009) Role of oxidative stress in alcoholinduced liver injury. Arch Toxicol 83(6):519-548

Dorn SB, Bolt HM, Thevis M, Diel P, Degen GH (2008) Induction of micronuclei in V79 cells by the anabolic doping steroids tetrahydrogestrinone and trenbolone. Arch Toxicol 82(4):257-263

Fabian E, Landsiedel R, Ma-Hock L, Wiench K, Wohlleben W, van Ravenzwaay B (2008) Tissue distribution and toxicity of intravenously administered titanium dioxide nanoparticles in rats. Arch Toxicol 82(3): 151-157

Florl AR, Schulz WA (2008) Chromosomal instability in bladder cancer. Arch Toxicol 82(3):173-182

Glahn F, Schmidt-Heck W, Zellmer S, Guthke R, Wiese J, Golka K, Hergenröder R, Degen GH, Lehmann T, Hermes M, Schormann W, Brulport M, Bauer A, Bedawy E, Gebhardt R, Hengstler JG, Foth H (2008) Cadmium, cobalt and lead cause stress response, cell cycle deregulation and increased steroid as well as xenobiotic metabolism in primary normal human bronchial epithelial cells which is coordinated by at least nine transcription factors. Arch Toxicol 82(8):513-524

Grotto D, Barcelos GR, Valentini J, Antunes LM, Angeli JP, Garcia SC, Barbosa F Jr (2009) Low levels of methylmercury induce DNA damage in rats: protective effects of selenium. Arch Toxicol 83(3):249-254

Kehe K, Raithel K, Kreppel H, Jochum M, Worek F, Thiermann H (2008) Inhibition of poly(ADP-ribose) polymerase (PARP) influences the mode of sulphur mustard (SM)-induced cell death in HaCaT cells. Arch Toxicol 82(7):461-470

Khalil WK, Ahmed KA, Park MH, Kim YT, Park HH, Abdel-Wahhab MA (2008) The inhibitory effects of garlic and Panax ginseng extract standardized with ginsenoside $\operatorname{Rg} 3$ on the genotoxicity, biochemical, and histological changes induced by ethylenediaminetetraacetic acid in male rats. Arch Toxicol 82(3):183-195

Lankisch TO, Gillman TC, Erichsen TJ, Ehmer U, Kalthoff S, Freiberg N, Munzel PA, Manns MP, Strassburg CP (2008) Aryl hydrocarbon receptor-mediated regulation of the human estrogen and bile acid UDP-glucuronosyltransferase 1A3 gene. Arch Toxicol 82(9):573-582

Liebers V, Raulf-Heimsoth M, Brüning T (2008) Health effects due to endotoxin inhalation (review). Arch Toxicol 82(4):203-210

Lilienblum W, Dekant W, Foth H, Gebel T, Hengstler JG, Kahl R, Kramer PJ, Schweinfurth H, Wollin KM (2008) Alternative methods to safety studies in experimental animals: role in the risk assessment of chemicals under the new European Chemicals Legislation (REACH). Arch Toxicol 82(4):211-236
Mahmud H, Föller M, Lang F (2009) Arsenic-induced suicidal erythrocyte death. Arch Toxicol 83(2):107-113

Manna P, Sinha M, Sil PC (2008) Arsenic-induced oxidative myocardial injury: protective role of arjunolic acid. Arch Toxicol 82(3):137-149

Matés JM, Segura JA, Alonso FJ, Márquez J (2008) Intracellular redox status and oxidative stress: implications for cellproliferation, apoptosis, and carcinogenesis. Arch Toxicol 82(5):273-299

Naraharisetti SB, Aggarwal M, Sarkar SN, Malik JK (2008) Concurrent subacute exposure to arsenic through drinking water and malathion via diet in male rats: effects on hepatic drug-metabolizing enzymes. Arch Toxicol 82(8):543-551

Nishimura J, Dewa Y, Okamura T, Muguruma M, Jin M, Saegusa Y, Umemura T, Mitsumori K (2008) Possible involvement of oxidative stress in fenofibrate-induced hepatocarcinogenesis in rats. Arch Toxicol 82(9):641-654

Pelkonen O, Turpeinen M, Hakkola J, Honkakoski P, Hukkanen J, Raunio H (2008) Inhibition and induction of human cytochrome P450 enzymes: current status. Arch Toxicol 82(10):667-715

Rezende VB, Barbosa F Jr, Montenegro MF, Sandrim VC, Gerlach RF, Tanus-Santos JE (2008) Haplotypes of vitamin D receptor modulate the circulating levels of lead in exposed subjects. Arch Toxicol 82(1):29-36

Schug M, Heise T, Bauer A, Storm D, Blaszkewicz M, Bedawy E, Brulport M, Geppert B, Hermes M, Föllmann W, Rapp K, Maccoux L, Schormann W, Appel KE, Oberemm A, GundertRemy U, Hengstler JG (2008) Primary rat hepatocytes as in vitro system for gene expression studies: comparison of sandwich, Matrigel and 2D cultures. Arch Toxicol 82(12):923-931

Settels E, Bernauer U, Palavinskas R, Klaffke HS, Gundert-Remy U, Appel KE (2008) Human CYP2E1 mediates the formation of glycidamide from acrylamide. Arch Toxicol 82(10):717-727

Son HY, Kim SH, Shin HI, Bae HI, Yang JH (2008) Perfluorooctanoic acid-induced hepatic toxicity following 21-day oral exposure in mice. Arch Toxicol 82(4):239-246

Strassburg CP, Lankisch TO, Manns MP, Ehmer U (2008) Family 1 uridine-5' -diphosphate glucuronosyltransferases (UGT1A): from Gilbert's syndrome to genetic organization and variability. Arch Toxicol 82(7):415-433

Sugawara N, Ohba T, Nakai K, Kakita A, Nakamura T, Suzuki K, Kameo S, Shimada M, Kurokawa N, Satoh C, Satoh H (2008) Effects of perinatal coexposure to methylmercury and polychlorinated biphenyls on neurobehavioral development in mice. Arch Toxicol 82(6):387-397

Thum T, Borlak J (2008) Detection of early signals of hepatotoxicity by gene expression profiling studies with cultures of metabolically competent human hepatocytes. Arch Toxicol 82(2):89-101

Verstraeten SV, Aimo L, Oteiza PI (2008) Aluminium and lead: molecular mechanisms of brain toxicity. Arch Toxicol 82(11):789-802

Westerink WM, Stevenson JC, Schoonen WG (2008) Pharmacologic profiling of human and rat cytochrome $\mathrm{P} 4501 \mathrm{~A} 1$ and $1 \mathrm{~A} 2$ induction and competition. Arch Toxicol 82(12):909-921

Yang CS, Lambert JD, Sang S (2009) Antioxidative and anti-carcinogenic activities of tea polyphenols. Arch Toxicol 83(1):11-21 